\title{
ACCESSIBILITY INDEX ANALYSIS OF MEDAN SUB- DISTRICT REGION: A DUAL APPROACH
}

\author{
RIDWAN ANAS, MEDIS S SURBAKTI \& IKA PUJI HASTUTY \\ Department of Civil Engineering, Universitas Sumatera Utara, Indonesia
}

\begin{abstract}
Accessibility is a concept that combines land use with transport service networks that connect and facilitates movements between locations or regions. Cities are built based on transportation planning and should provide adequate access to the activities of the region. This paper measured the accessibility index of the sub-district region in Medan by applying two approaches. Attention is given to highlight the differences in transport accessibility measurement results. The results determine the disparities of transport services in each of the sub-district. Identifying the accessibility index can be used to evaluate the policies encouraging public transport use in Medan. The public transport system should be developed based on high-density corridors and corridors poorly served by existing public transport to suppress private vehicles' increase in urban areas. Improvement of public transport services is mandatory to fulfill the accessibility of the region and minimize the tendency for road-oriented development (traditional approach) only. The public transport routes and total fleet operations seem to be a crucial issue to encourage private vehicle owners to use public transport by increasing the accessibility index of the region.

Keywords: accessibility, accessibility index, public transport services, road network, land use and transport.
\end{abstract}

\section{INTRODUCTION}

Transportation is a derived demand and designed to help people participate in activities distributed over space and time, in which transportation needs are derived from the size of economic activities of the region and individual activity patterns. Cities are built based on careful transportation planning; this reflects the importance of transportation on land use [1]. Urban development is influenced by individual transportation choices and involves transportation planning decisions [2]. The debate on the linkage between transportation and land use is not new, whether land use affects transportation or transportation provides reasonable access for a region [3].

Accessibility and mobility are the outcomes of most transport investment, where public transport and road networks play a critical role in urban settings. Accessibility is the ease for which desired activities can be reached from any particular location, a concept in several scientific fields such as transport planning, urban planning that combines land use with transport services to facilitate movements between regions and plays an essential role in policymaking [4]. Urban structure determines travel demand and travel patterns. Meanwhile, the transport supply influences urban structure [5], the accessibility is an essential indicator for measuring regional transportation costs and is often conceptualized as the benefits arising from welldeveloped transportation infrastructure [6].

Medan is one of the five big cities in Indonesia, with population growth was around 1\%, and GDP growth was around 5\% [7]. The residential area's growth is advancing rapidly, along with the development of the city. Economic development and high population growth in Medan have made a significant number of motorization and urbanization. Congestion becomes a big issue, in line with population and economic growth, while the number of private vehicle growth $( \pm 9.8 \%)$ does not balance with the road networks' growth $( \pm 0.7 \%)$. Due 
to the poor service of existing public transport and cheap motorcycle use [8;9], Medan has a very high private vehicle share $( \pm 71 \%$ motorcycle and $\pm 22 \%$ passenger car), which offers greater movement flexibility. Road networks facilitate transport services and other economic activities. Many big cities in Indonesia face the unbalanced growth between the vehicles and the road networks [10]. Strengthening the public transport system is an alternative solution to solve the imbalance problem other than increasing road capacity, and it also encourages people to use public transport.

The purpose of this paper was to build on the correlation between accessibility and people density across geographical areas by using a case study approach. It is an approach that adopts location-based perceptions at the regional level. The first issue is presented the transport services of the sub-district region in Medan using dual approaches (a comparison of public transport and road networks level of services). The second issue is a correlation between density and the accessibility index. After discussing related works, transportation quality determines the quality and advantage of a location relative to other locations [11]; this allows for evaluating the transportation system's policies.

\section{LITERATURE REVIEW}

\subsection{Accessibility measure}

Accessibility is essential for urban development, people and goods to support the regional economy [12]. There has been much development of accessibility in the last few decades into a measurable concept through academic research that discusses how to measure accessibility and the implementation of the accessibility concept in urban planning and transportation.

Traditionally, measures used to evaluate the transportation system have focused on mobility by assessing the potential movement. They include elements that describe design speed, road capacity, and level of service. Measurement of the linkage of transportation and land use falls into the general category of accessibility measures. These measures assess the ease of interaction and their ability to represent land use and the region's transportation system aspects [13].

Roughly, accessibility measures can be classified into two categories: place-based and individual-based measures [14]. Place-based measures analyse the accessibility at locations, typically on a macro-level. The measures describe the level of accessibility to spatially distributed activities, explicitly incorporate capacity restrictions of supplied activity characteristics to include competition effects.

\subsection{Aggregate measures of combined transport and land-use system}

Knox argues that it is the accessibility per person in a zone that needs to be measured, not the accessibility of a zone [15]. The disaggregate approach is an essential quality of accessibility measure [16]. While many accessibility measures provide information at a disaggregate level, many researchers agree that accessibility is a combination of the transportation system and land-use patterns [17]. The aggregate level should be considered when trying to measure the accessibility of a location, with the level of aggregation can change, but the location of the point in question is constant [18].

Several kinds of literature have been reviewed to understand the aggregate technique for measuring accessibility, as follows. 
Table 1: Accessibility measurement - an overview [13].

\begin{tabular}{|c|c|c|}
\hline $\begin{array}{l}\text { Aggregation } \\
\text { technique }\end{array}$ & Type of measure & Pros \& Cons \\
\hline $\begin{array}{l}\text { Spatial } \\
\text { Aggregation } \\
{[14 ; 19]}\end{array}$ & $\begin{array}{l}\text { Measures travel impediment or } \\
\text { resistance between origin and } \\
\text { destination, or between nodes. }\end{array}$ & $\begin{array}{l}\text { - A set of general assumptions } \\
\text { can present the framework for a } \\
\text { discrete choice model. } \\
\text { - Applicable for a utility-based } \\
\text { accessibility measure. } \\
\text { - Provides a mechanism to account } \\
\text { for the shape of aggregate spatial } \\
\text { units in spatial choice models } \\
\text { (Ferguson and Kanaroglou, } \\
\text { 1998). } \\
\text { Data is generally readily } \\
\text { available from digital mapping } \\
\text { material and other public sources. }\end{array}$ \\
\hline \multirow[t]{2}{*}{$\begin{array}{l}\text { Intermodal } \\
\text { Aggregation } \\
{[20 ; 21]}\end{array}$} & $\begin{array}{l}\text { Reflect the interaction between } \\
\text { land-use and transportation } \\
\text { supply modes. }\end{array}$ & $\begin{array}{l}\text { The accessibility should increase } \\
\text { as another mode is added to an } \\
\text { area. }\end{array}$ \\
\hline & $\begin{array}{l}\text { Used a weighted } \\
\text { average approach to aggregate } \\
\text { accessibility as a measure of } \\
\text { effectiveness of networks } \\
\text { measures }\end{array}$ & $\begin{array}{l}\text { This method accounts for } \\
\text { changes in transportation supply } \\
\text { better than does a conventional } \\
\text { gravity model (single mode). } \\
\text { An increase in transport supply } \\
\text { will increase transportation } \\
\text { accessibility. }\end{array}$ \\
\hline $\begin{array}{l}\text { Aggregation } \\
\text { over trip } \\
\text { purposes [22] }\end{array}$ & $\begin{array}{l}\text { Defined and interpreted for a } \\
\text { specific trip purpose or activity } \\
\text { of suburban communities }\end{array}$ & $\begin{array}{l}\text { Measurement not only for } \\
\text { activities but the magnitude of } \\
\text { activity in a particular location. }\end{array}$ \\
\hline
\end{tabular}

Each city has developed its unique spatial structure and transport system to provide access. Simultaneously, the critical thing in urban planning is supply-oriented rather than the accessibility to locations [23].

\subsection{Urban density and transportation}

There has been substantial discussion among planners about the influence of transportation and urban density [24]. A growing population and economy of urban areas will generate traffic and fundamentally will change the transport pattern [25], better or more efficient transportation access will impact the economy and agglomeration of a region [26]. The density is usually computed as a population per square kilometre $\left(\mathrm{km}^{2}\right)$ of land area, and strongly linked to automobile dependence and similarly with public transport services. 
In response to high urbanization rates in developing countries, Medan, with more than 1 million inhabitants and a population density of more than 5,000 people per square kilometers, is defined as a metropolitan city. Most Indonesian metropolitan cities are facing severe public transport problems. According to various data, in the last five years, the growth of registered vehicles in Indonesia has increased by almost $50 \%$, the highest growth was motorbike $(56.5 \%)$ and followed by car (35.7\%), bus (19.5\%) and truck $(13.7 \%)$.

Due mainly to higher personal incomes in Medan, car ownership was 16 per 1,000 inhabitants, and the motorcycle was 99 per 1,000 inhabitants in 2019 [7]. It has led to the inefficient use of urban space by private vehicles and provides a particular challenge for dense and developing cities where contemporary motorization far outpaces the provision of road infrastructure or public transit alternatives [27].

\section{METHOD}

Accessibility is a frequently used concept, but there is no consensus about its definition and formulation. It determines the location advantage of an area. The measurement developed is intended for location-based viewpoint: an application of graph theory and spatial separation measures. Also, to describe the correlation between transportation affordability and people density for transportation planning at the regional level.

The accessibility index among the region captured transport services' disparities based on public transport services and road networks. Therefore, the aggregate accessibility index value across regions as follows:

\subsection{Accessibility Index based on the service quality of public transport}

Public transport plays a crucial role in ensuring accessibility to activities and services. There are many influences on public transport, including spatial access, cost, physical accessibility, information and the coverage area, contributing to people's ability to use public transport.

In delivering public transport services, service planning makes assumptions about walking distance to access public transport. Guidelines often use one-quarter mile or $400 \mathrm{~m}$, Helsinki uses $300 \mathrm{~m}$, while Perth uses $500 \mathrm{~m}$ [28]. In this study, the coverage area examines the accessibility index based on public transport within walking distance $(400 \mathrm{~m})$ along the public transport route. Measurement of the accessibility refers to the ability of the public transport network services. According to the following formulation, GIS was used to draw the accessibility index maps of different public transport services and calculated public transport performance.

$$
A I=\sum \frac{\operatorname{Ptn} x \operatorname{Trn} x C}{A}
$$

The accessibility of a district comes from the summing of the total length of the route each sub-district (Ptn), then multiple the number of trips (Trn) per day and capacity of bus/paratransit $(C)$, with $A$ is total area for each sub-district region $\left(\mathrm{km}^{2}\right)$.

Besides the public transport services, in this study, walking distance to public transport is a critical element of establishing equitable access to public transport and an area, increasing the public transport facilities or routes not guarantee in line with increasing the accessibility of a region or reduces the demand for automobile, with make sure that the coverage area around the route incorporates with it. 


\subsection{Accessibility Index based on the road network}

This approach builds on traditional physical infrastructure measures such as road density and availability, adopted from the Rural Access Index (RAI). Accessibility is affected by the length of the road network, habitable land area, road distribution and population distribution.

Measurement of the accessibility index is calculated based on road network availability compares with the total area for each sub-district [28] by the following formula:

$$
A I=\frac{\text { total area of road }\left(\mathrm{km}^{2}\right)}{\text { total area }\left(\mathrm{km}^{2}\right)}
$$

The accessibility indexes' importance based on the road network examines equity and distributive justice of transport policies, especially road investment. It requires a complete understanding of accessibility than traditional indicators offer, only focus on road capacity while not compromising efficiency and ease of access.

\subsection{The linkage between Population Density and Accessibility Index}

The population is one of the most basic indices for estimating human statistics, and the relationship between population density and various values has been investigated by several researchers. Due to high urbanization rates in developing countries, the literature on the relationship between land use and public transport viability has been dominated by city population density [29]. The linkages analysis investigates the relevance of public transport services and road facilities that contribute to the urban populations in Medan.

Simple linear regression is the most common method to determine the strength of a relationship between two item sets by using one variable to predict or explain another variable in terms of a linear relationship. A linear model predicts the population density value as a dependent variable $(y)$ against the accessibility index value as an independent variable $(x)$.

Linear correlation analysis is a tool for representing the linkage of one related variable to another, which can be a dependent and an independent variable. Correlation analysis is a widely used statistical measure and identified relations among different attributes of datasets. The correlation coefficient is meant for quantifying such a degree of relationship between the variables. The correlation coefficient of the regression line of $y$ on $x$ must lie in the range $0<|r|<1$. The Correlation analysis conducted in this research can be defined as follows.

$$
r=\frac{n \sum x y-\sum x \sum y}{\sqrt{\left[n \sum x^{2}-\left(\sum x\right)^{2}\right]\left[n \sum y^{2}-\left(\sum y\right)^{2}\right]}}
$$

Where:

$R=$ The correlation coefficient

$y=$ The dependent variable value

$x=$ The independent variable value 
The significant relationship between the dependent and independent variables can be confirmed with their significant linear correlation coefficient. The coefficient of determination $\left(R^{2}\right)$ is the measure that gives the validity of the dependent variable's prediction with the independent variable. It provides information about the dependent variable's variation explained by the model's predictors [30].

$$
R^{2}=\frac{S S R}{S S T}
$$

where:

$R \quad=$ coefficient of determination of the regression equation

$\mathrm{SSR}=$ Sum of squared regression

SST $=$ Total variation in the data

\section{RESULT AND ANALYSIS}

4.1 Comparative analysis of the accessibility index

As a case study, Medan was selected because it is a private vehicle-dominated city like many developing cities in Indonesia. According to the Ministry of Transportation in 2017, public transport quality of service in Medan is declining. There were 109 routes, with a total of 6,700 units registered to operate. Most recent data collection shows that the number of still
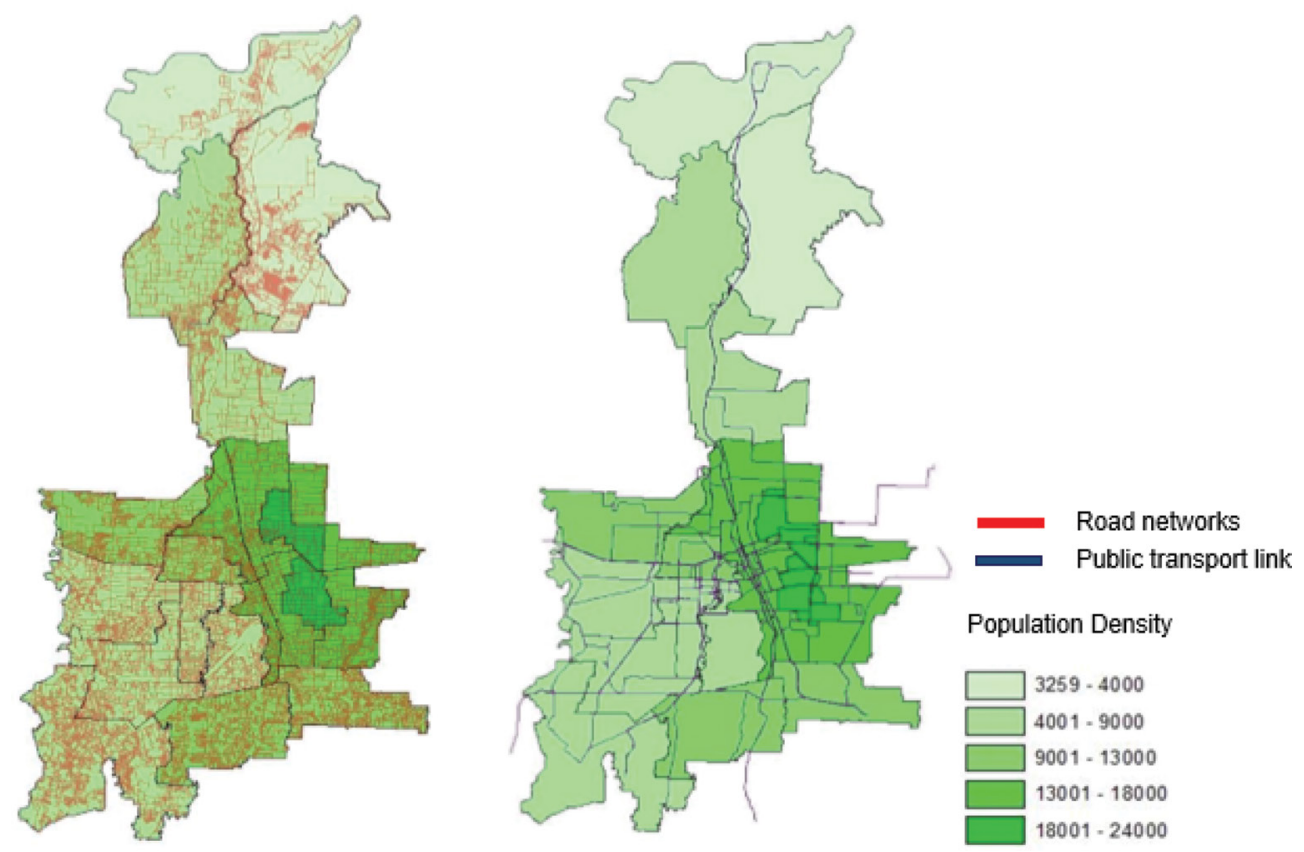

Figure 1: Road networks and Public transportation routes in Medan. 
operating routes has been far reduced (+60 routes), with numbers of the fleet operating in 2019 smaller than the numbers registered (3,335 units).

This section is intended to determine the dual approach to measure the accessibility index of the sub-district region in Medan, as shown in the following figure.

Accessibility index based on public transport services, show disparities of transport services each of the sub-district region. The accessibility index per sub-district can be seen in the following table.

Table 2 shows the accessibility index value of each sub-district in Medan. Medan Baru sub-district has the highest accessibility index value based on public transport services. The result shows that 154 out of $265 \mathrm{~km}^{2}$ (around 58\%) are not covered by the public transport services (bus and paratransit).

The accessibility index value is based on road networks. Medan consists of 10,250 links and 4,130 nodes, with a total length of roads was $3,279.5 \mathrm{~km}$, and a total road area was

Table 2: Accessibility Index of the sub-district region.

\begin{tabular}{|c|c|c|c|c|c|c|}
\hline \multirow[t]{2}{*}{ No. } & \multirow[t]{2}{*}{ District } & \multicolumn{3}{|c|}{ Public transport services } & \multicolumn{2}{|c|}{ Road networks } \\
\hline & & $\begin{array}{l}\text { Length of } \\
\text { route } \\
(\mathrm{km})\end{array}$ & $\begin{array}{l}\text { Number } \\
\text { of trips }\end{array}$ & $\begin{array}{l}\text { Accessibility } \\
\text { Index }\end{array}$ & $\begin{array}{l}\text { Total area } \\
\text { of road } \\
\left(\mathrm{km}^{2}\right)\end{array}$ & $\begin{array}{l}\text { Accessibility } \\
\text { Index }\end{array}$ \\
\hline 1 & Medan Tuntungan & 85.95 & 555 & $4,717.83$ & 1.02 & 0.05 \\
\hline 2 & Medan Johor & 59.55 & 375 & $3,598.03$ & 2.56 & 0.14 \\
\hline 3 & Medan Amplas & 87.32 & 490 & $4,903.37$ & 1.53 & 0.14 \\
\hline 4 & Medan Denai & 41.36 & 239 & $2,534.25$ & 0.81 & 0.09 \\
\hline 5 & Medan Area & 37.19 & 237 & $2,496.47$ & 0.62 & 0.11 \\
\hline 6 & Medan Kota & 56.77 & 348 & $2,877.21$ & 0.77 & 0.15 \\
\hline 7 & Medan Maimun & 37.31 & 264 & $2,308.60$ & 0.28 & 0.09 \\
\hline 8 & Medan Polonia & 19.04 & 102 & $1,189.43$ & 0.60 & 0.07 \\
\hline 9 & Medan Baru & 103.86 & 626 & $6,206.51$ & 0.61 & 0.10 \\
\hline 10 & Medan Selayang & 61.89 & 352 & $3,785.10$ & 0.91 & 0.07 \\
\hline 11 & Medan Sunggal & 89.66 & 516 & $5,341.83$ & 1.07 & 0.07 \\
\hline 12 & Medan Helvetia & 95.73 & 497 & $5,559.58$ & 1.25 & 0.09 \\
\hline 13 & Medan Petisah & 91.63 & 405 & $5,164.33$ & 0.66 & 0.09 \\
\hline 14 & Medan Barat & 112.46 & 674 & $6,179.76$ & 0.63 & 0.1199 \\
\hline 15 & Medan Timur & 67.98 & 350 & $4,163.21$ & 1.06 & 0.14 \\
\hline 16 & Medan Perjuangan & 51.82 & 377 & $3,289.05$ & 0.62 & 0.15 \\
\hline 17 & Medan Tembung & 54.50 & 249 & $3,068.42$ & 0.63 & 0.08 \\
\hline 18 & Medan Deli & 99.42 & 401 & $2,674.04$ & 1.28 & 0.06 \\
\hline 19 & Medan Labuhan & 46.66 & 196 & $2,143.43$ & 1.04 & 0.03 \\
\hline 20 & Medan Marelan & 28.09 & 112 & $1,221.33$ & 0.99 & 0.04 \\
\hline 21 & Medan Belawan & 40.42 & 178 & $1,805.59$ & 0.66 & 0.02 \\
\hline
\end{tabular}


around $19,677 \mathrm{~km}^{2}$. From the table above, it is determined that 11 districts have accessibility index values below the average.

Plan a new road network that serves the unserved sub-districts region, but it will induce the automobile. On the other hand, increase the public transport facilities not guarantee reduces the demand for private vehicles, without making sure that the coverage area around the route incorporates with it. Nevertheless, this research's contribution is to move beyond comparing two methods; road density and land use patterns optimal for one mode are generally less suited for other modes. In this case, while roads designed for maximum accessibility will accommodate automobile access, they tend to have poor public transit.

Figure 2 shows the weighted accessibility index for each sub-district in Medan based on dual approaches. The results show that Medan Perjuangan sub-district has the highest accessibility index based on the availability of the road network, and Medan Baru sub-district has the highest accessibility index value based on public transport services. The analysis further showed different results in each sub-district area.

\subsection{Parametric comparison}

Linear regression tries to determine the best linear relationship between data points, while correlation coefficients assess the association (as opposed to agreement) between the accessibility indexes. The correlation analysis is applied to population density and accessibility index data based on the sub-district region. The summary of the accessibility index with population density and total area districts in Medan can be seen in the following table.

The first analysis assessed the relationship between population density and accessibility based on public transport and is illustrated in Fig. 3a. The second analysis, presented in Fig. $3 \mathrm{~b}$, explores the relationship between population density and accessibility based on the road network.

A high correlation coefficient proves the existence of a close mathematical relationship between the variables. Table 4 shows the linear regression model of dependent $(y)$ and independent $(x)$ variables for both regression models.

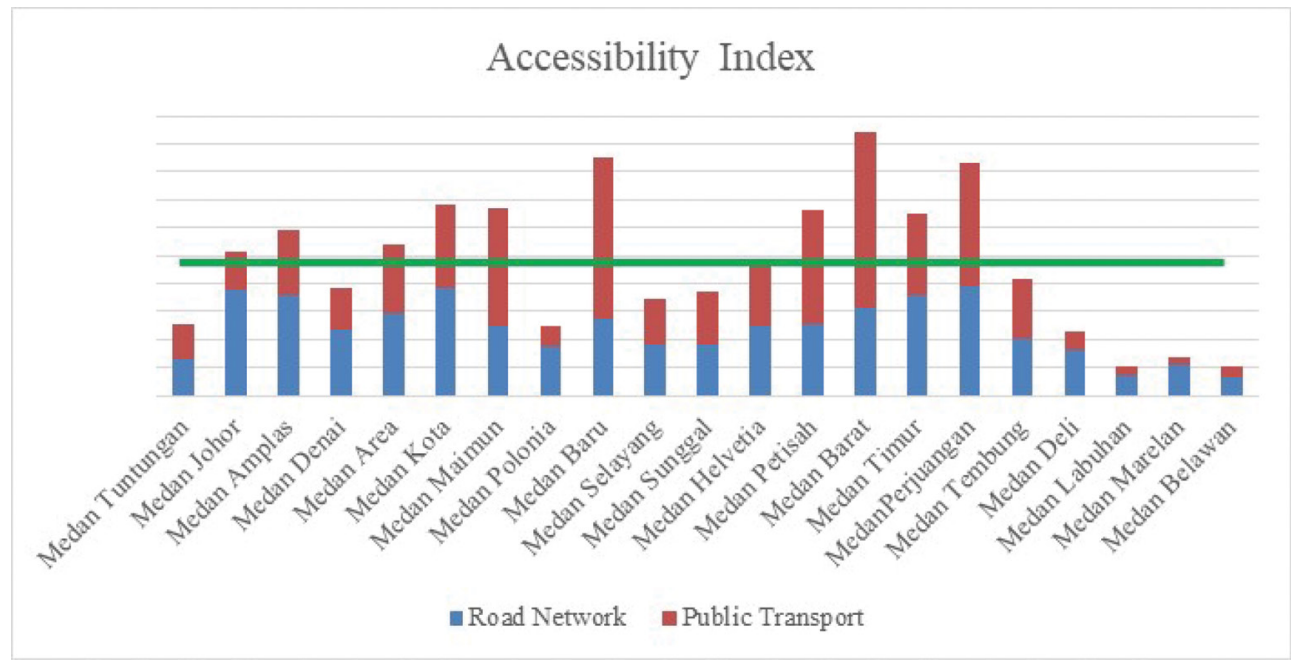

Figure 2: Accessibility Index per sub-district in Medan. 
Table 3: Accessibility Index per sub-district in Medan.

\begin{tabular}{|c|c|c|c|c|c|}
\hline \multirow[b]{2}{*}{ No. } & \multirow[b]{2}{*}{ Sub-district } & \multirow{2}{*}{$\begin{array}{l}\text { Population } \\
\text { density }\end{array}$} & \multirow{2}{*}{$\begin{array}{l}\text { Total } \\
\text { area } \\
\left(\mathrm{km}^{2}\right)\end{array}$} & \multicolumn{2}{|c|}{ Accessibility Index } \\
\hline & & & & $\begin{array}{l}\text { Public } \\
\text { transport }\end{array}$ & $\begin{array}{l}\text { Road } \\
\text { infrastructure }\end{array}$ \\
\hline 1 & Medan Tuntungan & $4,212.91$ & 20.68 & $4,717.83$ & 0.04 \\
\hline 2 & Medan Johor & $9,235.66$ & 14.58 & $3,598.02$ & 0.15 \\
\hline 3 & Medan Amplas & $11,381.68$ & 11.19 & $4,903.37$ & 0.11 \\
\hline 4 & Medan Denai & $16,306.18$ & 9.05 & $2,534.25$ & 0.07 \\
\hline 5 & Medan Area & $18,083.51$ & 5.52 & $2,496.46$ & 0.09 \\
\hline 6 & Medan Kota & $14,243.45$ & 5.27 & $2,877.21$ & 0.12 \\
\hline 7 & Medan Maimun & $13,765.10$ & 2.98 & $2,308.60$ & 0.08 \\
\hline 8 & Medan Polonia & $6,322.97$ & 9.01 & $1,189.42$ & 0.08 \\
\hline 9 & Medan Baru & $7,001.36$ & 5.84 & $6,206.50$ & 0.12 \\
\hline 10 & Medan Selayang & $8,485.71$ & 12.81 & $3,785.09$ & 0.06 \\
\hline 11 & Medan Sunggal & $7,563.01$ & 15.44 & $5,341.82$ & 0.06 \\
\hline 12 & Medan Helvetia & $11,611.39$ & 13.16 & $5,559.58$ & 0.08 \\
\hline 13 & Medan Petisah & $9,369.79$ & 6.82 & $5,164.33$ & 0.08 \\
\hline 14 & Medan Barat & $13,753.28$ & 5.33 & $6,179.76$ & 0.10 \\
\hline 15 & Medan Timur & $14,476.67$ & 7.76 & $4,163.20$ & 0.11 \\
\hline 16 & Medan Perjuangan & $23,645.72$ & 4.09 & $3,289.04$ & 0.18 \\
\hline 17 & Medan Tembung & $17,315.14$ & 7.99 & $3,068.42$ & 0.06 \\
\hline 18 & Medan Deli & $8,937.38$ & 20.84 & $2,674.04$ & 0.05 \\
\hline 19 & Medan Labuhan & $3,259.04$ & 36.67 & $2,143.42$ & 0.02 \\
\hline 20 & Medan Marelan & $7,109.23$ & 23.82 & $1,221.33$ & 0.03 \\
\hline 21 & Medan Belawan & $3,769.90$ & 26.25 & $1,805.59$ & 0.02 \\
\hline
\end{tabular}

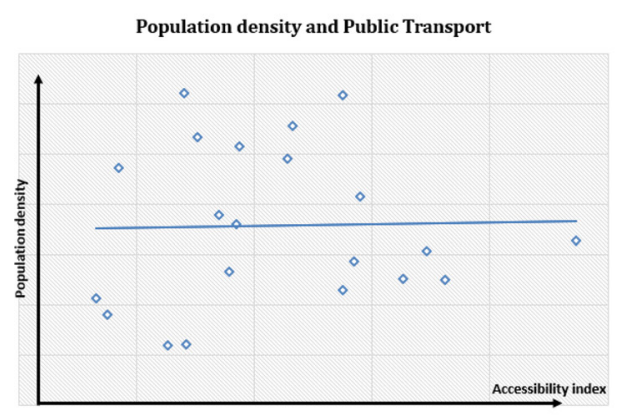

(a)

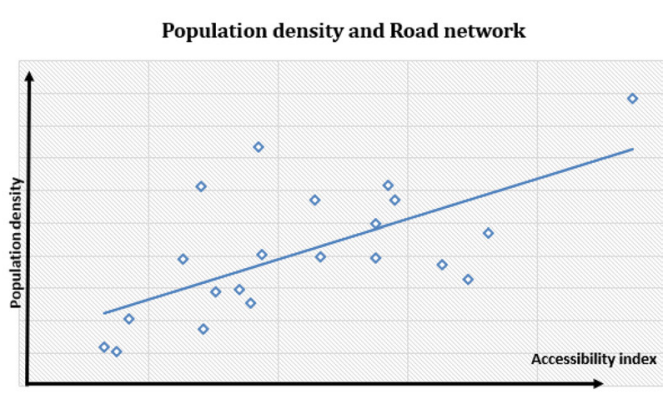

(b)

Figure 3: The relationship between population density and accessibility index (a) based on public transport; (b). based on road network. 
Table 4: Correlation between population density and transport system. (public transport services and road network)

\begin{tabular}{llll}
\hline 1st Regression statistics & \multicolumn{2}{l}{ 2nd Regression statistics } \\
\hline Multiple R & 0.022740817 & Multiple R & 0.644368932 \\
R Square & 0.000517145 & R Square & 0.41521132 \\
Adjusted R Square & -0.052087216 & Adjusted R Square & 0.384432969 \\
Standard error & 5407.363369 & Standard error & 4136.160271 \\
$P$-value & 0.922057366 & $P$-value & 0.001616477 \\
Observations & 21 & Observations & 21 \\
\hline
\end{tabular}

Based on public transport, simple linear regression analysis results in the equation $Y=0.0067 X+3,508.6$ and this relationship provides correlation coefficient $r=0.0227$ between the variables. The degree of association between the variables is a very weak or negligible correlation $(r<0.2)$, giving a coefficient of determination $R^{2}=0.0005$. It means that almost all of the total variation in $y$ cannot be explained by the linear relationship between $x$ and $y$ (as described by the regression equation).

Based on the road network, simple linear regression analysis results in the equation $Y=$ $5 \mathrm{E}-06 x+0.0289$ with $r=0.6443$, which means it had an enormously high correlation between two variables. The coefficient of determination $R^{2}=0.6443$, denotes the amount of contribution between accessibility index and population density is 0.6443 or $64.43 \%$, while other factors influence $35.57 \%$.

The coefficient of determination is the variance in the dependent variable predictable from the independent variable(s). A model including a set of predictors accounts for the variation in the response variable. It is used to compare models, including different numbers of predictors, and help model selection.

\section{CONCLUSION}

Good transportation accessibility is certainly an important factor in exploiting spatial potentials whereas the relationship between land use and public transport viability has been dominated by city population density. The quality of transportation infrastructure determines the quality and advantage of a location relative to other locations. Accessibility is a frequently used concept, but there is no consensus about its definition and formulation. This paper develops a measurement of sub-district accessibility index by using different transportation modes (public transport and road network), and then a comparison that reflects the interaction between each sub-district density patterns and transport supply modes.

Comprehensive metropolitan area transportation studies have increasingly recognized the effects of density on urban travel. Improvement of public transport services is mandatory to fulfil the accessibility of the region, no longer the tendency for road-oriented development (traditional approach), in that the inclination towards private vehicle usage will only get worse and often leads to suburban sprawl. Public transport routes and the total fleet operated seem to be a significant issue for attracting private car ownership to use public transport. Increasing the public transport services without extending the coverage area will not increase the accessibility index of the region. 
Transport investment and urban development must be based on a more balanced approach. It means transport programs must be paired with land-use policies. Measuring accessibility is challenging; the interrelationships between accessibility and urban development have focused on many studies directed to the indicators that evaluate whether accessibility contributes to urban structure.

Based on Medan's accessibility measurements, improving public transport services is more crucial than road network development. The development of road networks will accelerate urban density along these roads and attract more traffic. A better approach to this dilemma is to control developments and minimize their impacts on selected traffic routes. Related to the population's spatial distribution, this allows for evaluating the policies to encourage public transport use in Medan to suppress private vehicles' increase in urban areas.

However, this paper guides applying a dual approach perspective for measuring accessibility in urban areas. It can be seen from the different results in each district. This dual approach does not have a relationship between accessibility with travel time, travel costs and land value and needs further research.

Another finding reveals that a spatial coupling relationship between the distribution of urban consolidation and their accessibility to different transportation facilities was discernible by comparing the accessibility index and population of each sub-district area. This paper determines that the road network has an evident linkage for urban population density in Medan. It is shown that private car travel is the primary mode choice in Medan. The increment of road capacity and transport efficiency is a common problem faced by authorities. One of the practical approaches to address this problem is the integration of transport planning and urban planning.

The improvement of public transport is required to prevent congestion in main roads in Medan. The development of public transport should increase the accessibility of each subdistrict area, so the public authorities' requirements for integrating public transport services and urban planning. This study has implications for the stakeholders in developing public transport in Medan by highlighting the accessibility index of the sub-district regions to suppress the increase of private vehicles in Medan.

\section{ACKNOWLEDGEMENTS}

This work was supported by Universitas Sumatera Utara (4167/UN5.1.R/RPM/2019, 2019)

\section{REFERENCES}

[1] Štefančić, G., Šarić, Slavko. \& Spudić, R., Correlation between land use and urban public transport: a case study of Zagreb. Promet - Traffic \& Transportation, 26, pp. 179184, 2014.

[2] Trattner Z., Chronis, A., \& Muñoz, A., The Mobility Topography Model for Substantializing and Projecting Transportation in Cities. Proceeding of Architecture and Urban Design conferences, pp. 209-307, 2017.

[3] Wee, Bert van, Land use and transport: research and policy challenges. Journal of Transport Geography, 10, pp. 259-271, 2002.

[4] Bok, J., \& Kwon, Y., Comparable measures of accessibility to public transport using the general transit feed specification. Journal of Sustainability, 8, p 224, 2016.

[5] Cosra P. B., Morais, N.G.C., \& Bertolde, A.I., Urban mobility indexes: a brief review of the literature. Proceeding of World Conference on Transport Research, pp. 3649-3659, 2017. 
[6] Jiang, H., Xu, W., \& Zhang, W., Transportation accessibility and location choice of Japanese-Funded electronic information manufacturing firms in Shanghai. Journal of Sustainability, 10, p 390, 2018.

[7] Kota Medan dalam Angka, BPS-Statistics of Medan Municipality, pp. 57-72, 2019.

[8] Susilo, O.Y., Joewono, T.B., Santosa, W., \& Parikesit, D., A reflection of motorization and public transport in the Jakarta metropolitan area. IATSS Research. 31(1), pp. 59-67, 2007.

[9] Satiennam, T., Jaensirisak, S., Satiennam, W., \& Detdamrong, S., Potential for modal shift by passenger car and motorcycle users towards Bus Rapid Transit (BRT) in an Asian developing city. IATSS Research, 39, pp. 121-129, 2015.

[10] Idris, Z,.RW., Sri Prabandiyani, \& Riyanto, B., Implementation of management policy in urban public transportation based on user satisfaction in Yogyakarta agglomeration. International Journal of Civil Engineering and Technology (IJCIET), 10 (2), pp. 743 $750,2019$.

[11] Vulevic, A., Accessibility concepts and indicators in transportation strategic planning issues: theoretical framework and literature review. Logistics \& Sustainable Transport, 7 (1), pp. 58-67, 2016.

[12] Ford, A.C., Barr, S.L., Dawson, R.J., \& James, P., Transport accessibility analysis using GIS: assessing sustainable transport in London. International Journal of GeoInformation, 4, pp. 124-149, 2015.

[13] Development of an urban accessibility index: formulations, aggregation, and application Research; Texas Department of Transportation, pp. 5-6, 2002.

[14] Geurs, K.T. \& Wee, B.V., Accessibility evaluation of land-use and transport strategies review and research directions. Journal of Transport Geography, 12, pp. 127-140, 2004.

[15] Knox, P. L., The intraurban ecology of primary medical care: patterns of accessibility and their policy implications. Environment and Planning A, 10, pp. 415 - 435, 1978.

[16] Accessibility in urban areas: an overview of different indicators, National Institute for Transport and Road Research, CSIR, South Africa 1983.

[17] Handy, S.L., \& Niemeier, D.A., Measuring accessibility: an exploration of issues and alternatives. Environment and Planning A, 29, pp. 1175-1194, 1997.

[18] Bach, L., The problem of aggregation and distance for analyses of accessibility and access opportunity in Location-Allocation models. Environment and Planning A, 13, pp. 955-978, 1981.

[19] Akiva, B.M., \& Lerman, S., Discrete Choice Analysis: Theory and Application to Travel Demand, The MIT Press: Massachusetts. 1985.

[20] Davidson, K. B., Accessibility in Transport/Land-Use Modelling and Assessment. Environment and Planning A, 9, pp. 1401 - 1416, 1977.

[21] Levinson, D., \& Kumar, A., Multimodal trip distribution: structure and application. Transportation Research Record, 1466, pp. 124 - 131, 1994.

[22] Handy, S. L., Regional versus local accessibility: neo-traditional development and its implications for non-work travel. Built Environment, 18(4), pp. 253 - 267, 1993.

[23] Brussel, M., Zuidgeest, M., Pfeffer, K., \& Maarseveen, M.V., Access or accessibility? a critique of the urban transport SDG Indicator. Int. J. Geo-Inf., 8, pp. 67, 2019.

[24] Moeckel, R., Garcia, C.L., Chou, A.T.M., \& Okrah, M.B., Trends in integrated landuse/transport modeling: An evaluation of the state of the art. The Journal of Transport and Land use, 11(1), pp. 463-476, 2018. 
[25] Stanley, J.K., Land use/transport integration: Starting at the right place. Research in Transportation Economics, pp. 1-8, 2014.

[26] Accessibility in cities: transport and urban form; London School of Economics and Political Science, 2014.

[27] Accessibility measures: overview and practical Applications; Department of Urban and Regional Planning Curtin University, Online, http://wiki.dpi.inpe.br/lib/exe/. Accessed on: 21 August 2019.

[28] Daniels, R. \& Mulley, C., Explaining walking distance to public transport: The dominance of public transport supply. The Journal of Transport and Land Use, 6(2), pp. 5-20, 2013

[29] Cooke, S, \& Behrens, R., Correlation or cause? The limitations of population density as an indicator for public transport viability in the context of a rapidly growing developing city. Proceeding of World Conference on Transport Research - WCTR, pp. 3003-3016, 2016.

[30] Zhang, D., A coefficient of determination for generalized Linear Models, The American Statistician, pp 6-9, 2016. 